\author{
Tetiana Kostyshyna ${ }^{1}$, Larysa Stepanova², \\ Oleksandr Kravchenko ${ }^{3}$, Anna Kostyshyna ${ }^{4}$, Anna Smirnova ${ }^{5}$ \\ DOI: https://doi.org/10.15804/rop2021305
}

\title{
MANAGEMENT OF REGULATION PROCESSES FOR LABOR REMUNERATION AND PERSONNEL SECURITY OF ENTERPRISES
}

Keywords: remuneration, personnel safety, regulatory management, synergistic effect of self-organization

\begin{abstract}
A study of the management of the processes of regulation of remuneration in the context of ensuring the personnel security of enterprises proves that there is a close link between these management objects, which is conditioned by internal and external factors. The structural and functional components of the reference model of wage regulation have been determined, which makes it possible to form an effective motivational mechanism, increase
\end{abstract}

1 Doctor of Economics, Professor, Poltava University of Economics and Trade, Head of the Department of Personnel Management, Labor Economics and Economic Theory. tkost2017@gmail.comORCID: htpps://orcid.org/0000-0003-4776-5150.

2 Doctor of Economic Science (Ph.D.), Associate Professor, University of Poltava University of Economics and Trade, Associate Professor, Department of Personnel Management, Labor Economics and Economic Theory. Lara.stepanpwa@gmail.com, ORCID number: https://orcid.org/0000-0003-0483-5657.

3 University of Poltava University of Economics and Trade, Associate Professor, Department of Personnel Management, Labor Economics and Economic Theory. tkost2017@gmail.com. ORCID number: https://orcid.org/0000-0003-4171-1215.

4 University of Poltava University of Economics and Trade, postgraduate, Department of Personnel Management, Labor Economics and Economic Theory. e-mail: anna4229@ukr.net. ORCID number: https://orcid.org/0000-0002-0716-4468.

5 University of Poltava University of Economics and Trade, postgraduate, Department of Personnel Management, Labor Economics and Economic Theory. e-mail: sealineodessa@gmail.com. ORCID number: https://orcid.org/0000-0003-4742-7178. 
labor productivity, ensure personnel safety and competitiveness of the enterprise. The formed model of regulatory management of remuneration with the definition of synergistic effect allows to determine the sequence of processes on the organization of work of the mechanism of regulation of remuneration in the context of ensuring personnel security. The conducted cluster analysis allows to evaluate the enterprises of the regions of Ukraine by the level of regulation of remuneration and personnel threats.

\section{INTRODUCTION}

In the conditions of European integration and globalization, the competition in global markets with a high degree of representation of different actors requires Ukraine to develop a long-term well-balanced strategy of entering the world markets and application of effective mechanisms for processes managing in order to maintain their sustainable positions.

An effective prerequisite for the successful implementation of Ukrainian management strategy is effective social and economic development. The basis is management of organizational and economic processes in the field of labor with essential components (labor remuneration and personnel security).

To form an effective national economy, there needed certain prerequisites requiring appropriate changes in the management of labor remuneration and its regulation processes.

The processes of personnel security management of enterprises are top priority and urgency as they influence on: provision of economic security of state as a whole, development and growth rates of Ukrainian economy, formation of appropriate social and economic standards of modern model in terms of labor remuneration and quality as well as personnel security of enterprises.

Taking into account the effectiveness management in enterprises and national economy as a whole, the research, aimed at further improving management of labor remuneration regulation and personnel security policies, should be considered topical. 


\section{LITERATURE REVIEW}

Management of labor remuneration processes is highlighted in the works of Ukrainian scientists: M. Vedernikova, O. Doronina, A. Kolota, T. Kostyshina, I. Petrova, M. Semikina, S. Tsymbaliuk, A. Chernushkina and others. Some issues regarding the definition of the concept of "personnel security" and "management of personnel security" were considered in the works of local and foreign scientists, among them: A. Alverdov, O. Amosov, N. Gavkolova, Z. Zhivko, A. Kibanov, V. Kravchenko, O. Lyashenko, G. Nazarova, A. Cherep and others.

Despite the wide range of issues covered by the studies of foreign and local scientists, the current issues related to the management of labor remuneration processes in the context of providing personnel security in enterprises are insufficiently studied and expanded. The factors of expediency for the research - regulation processes of social and labor relations in labor market of Ukraine and development of national economy, associated with increase of personnel threats. There are certain reasons to believe that the development of mechanism for labor remuneration in the national economy, reference model of regulation for labor remuneration, distinguishing the directions for implementation of mechanism and sequence of labor remuneration processes in the context of personnel security providing, the introduction of a mechanism of synergy for personnel security and labor remuneration level to improve management of regulation processes for labor remuneration in the context of personnel security providing.

The studies aimed to improve management of regulation processes for labor remuneration in the context of personnel security providing. To achieve this goal, the following tasks were to be solved:

- determine the mechanism of labor remuneration in national economy, taking into account the influence of external and internal factors;

- determine structural and functional components of the reference model for regulation processes of labor remuneration;

- form a model for regulation processes of labor remuneration with the definition of synergy effect of self-organization; 
- distinguish the organization for regulation processes of labor remuneration mechanism in the context of personnel security providing;

- perform a cluster analysis and construct a matrix for assessment of personnel security synergy effect on the level of labor remuneration.

\section{METHODOLOGY AND RESEARCH METHODS}

Theoretical and methodological basis of the research is fundamental positions of economic theory, labor economics and social and labor relations, personnel management, and enterprise security. The objective is to use such methods: analysis and synthesis, induction, deduction and systematization - for generalization and grouping of personnel security components, allocation of influence factors on personnel security providing; logical generalization and comparison - for a cluster analysis of synergy effect of personnel security influence on the level of labor remuneration; economic-statistical analysis - for identification trends in the situation of labor remuneration regulation in the context of personnel security providing; method of formalization - for substantiating the elements of reference model for labor remuneration regulation; matrix positioning - for grouping the studied regions of Ukraine by the level of synergy effect of personnel security on the level of labor remuneration.

\section{RESULTS}

Set of main external and internal factors influencing mechanism of labor remuneration in functioning of national economy system is presented in Fig. 1.

As shown in Fig. 1, mechanism of labor remuneration in a market economy is a combination and a definite interaction of the following sections: 1) regulation of demand and supply of labor force in labor market; 2) state regulation processes for labor remuneration; 3) collective-contract regulation; 4) internal management of labor remuneration. 


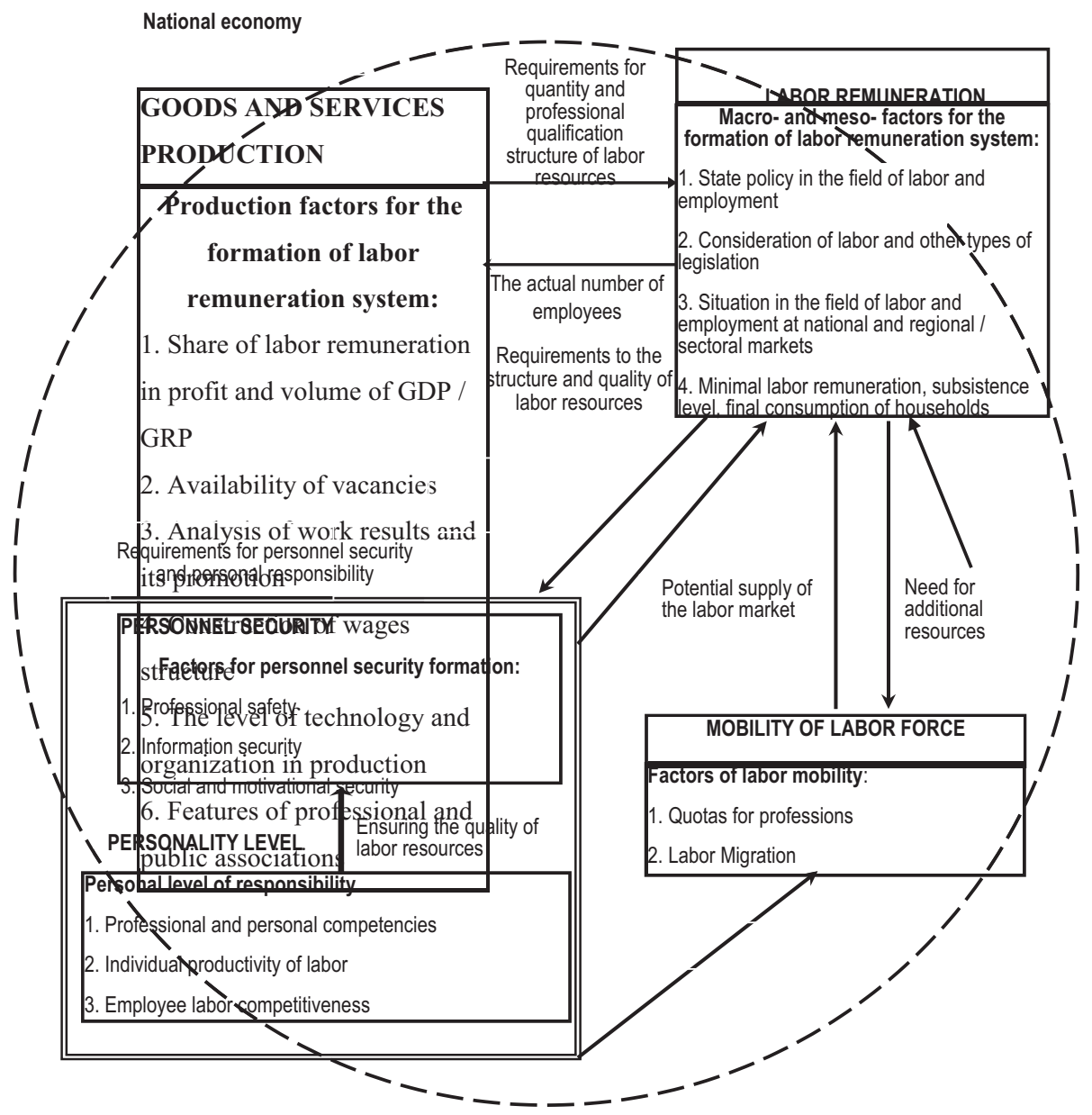

Fig. 1. Mechanism of labor remuneration in national economy: the scheme of interaction of elements of external and intern

The formed regulation processes of labor remuneration in the context of providing personnel security of enterprises is a reflection of the subjective view of how the labor remuneration system works, how it interacts with the external environment, the way main players (state, business units (enterprises), employees and other stakeholders) interact with each other. It is possible to do this model using IDEF0 methodology. 
The model in the methodology IDEF0 is a hierarchical sequence of interconnected diagrams based on the principle of "matryoshka". The first (outer) layer of "matryoshka" is a context diagram that displays the context of the system at the level of communications with the external environment (Fig. 2)

To illustrate the set of regulation processes for labor remuneration, a reference model has been developed, the context diagram is presented in Fig. 3, using the software tool for modeling processes "BPwin" methodology IDEF0.

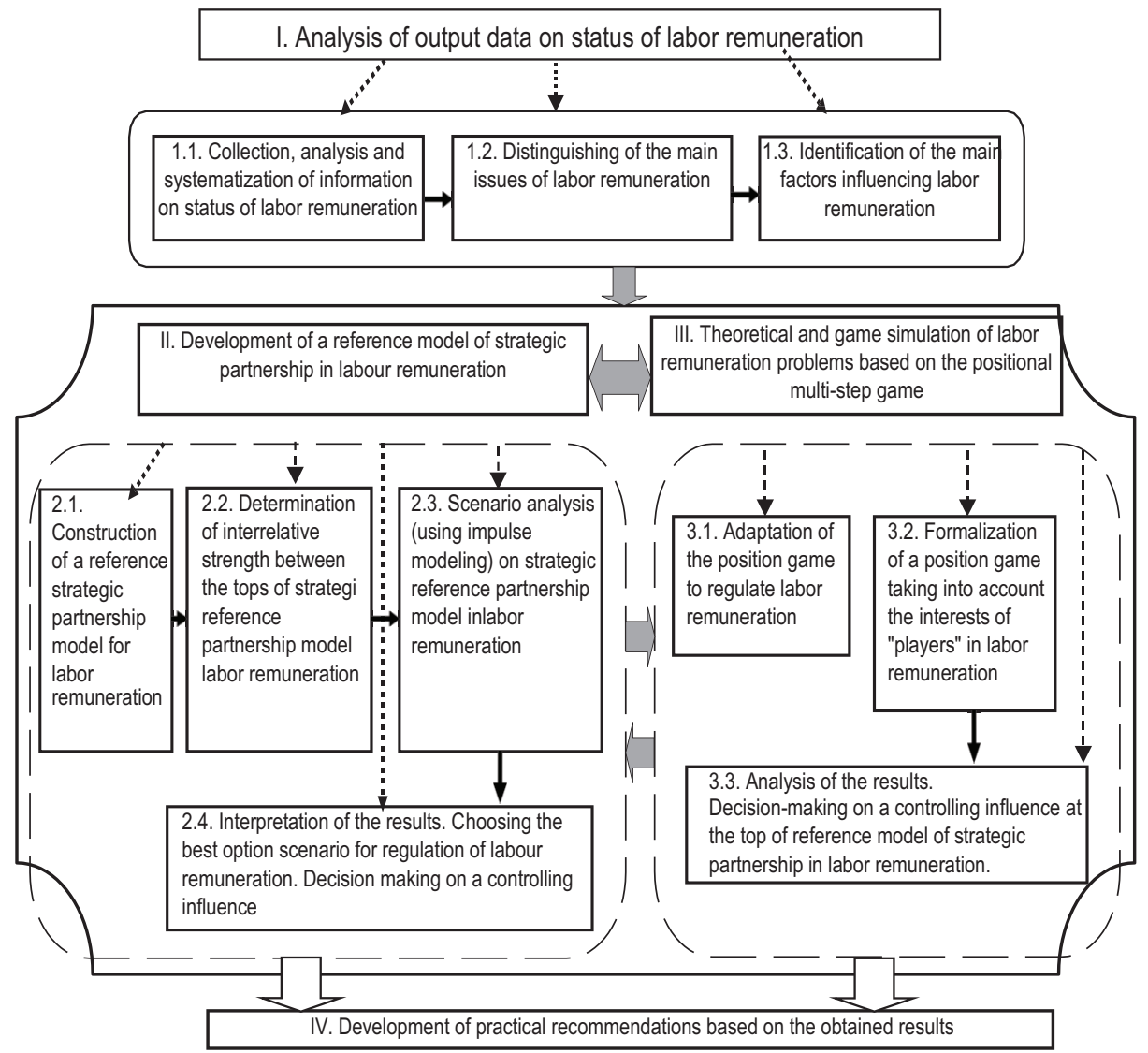

Fig. 2. Structural-functional components of the reference model of regulation processes for labor remuneration 
Context: development of strategic guidelines for regulation processes of CONTROL labor remuneration through the formation of synergy interaction of all stakeholders on the basis of classification according to the factors of influence

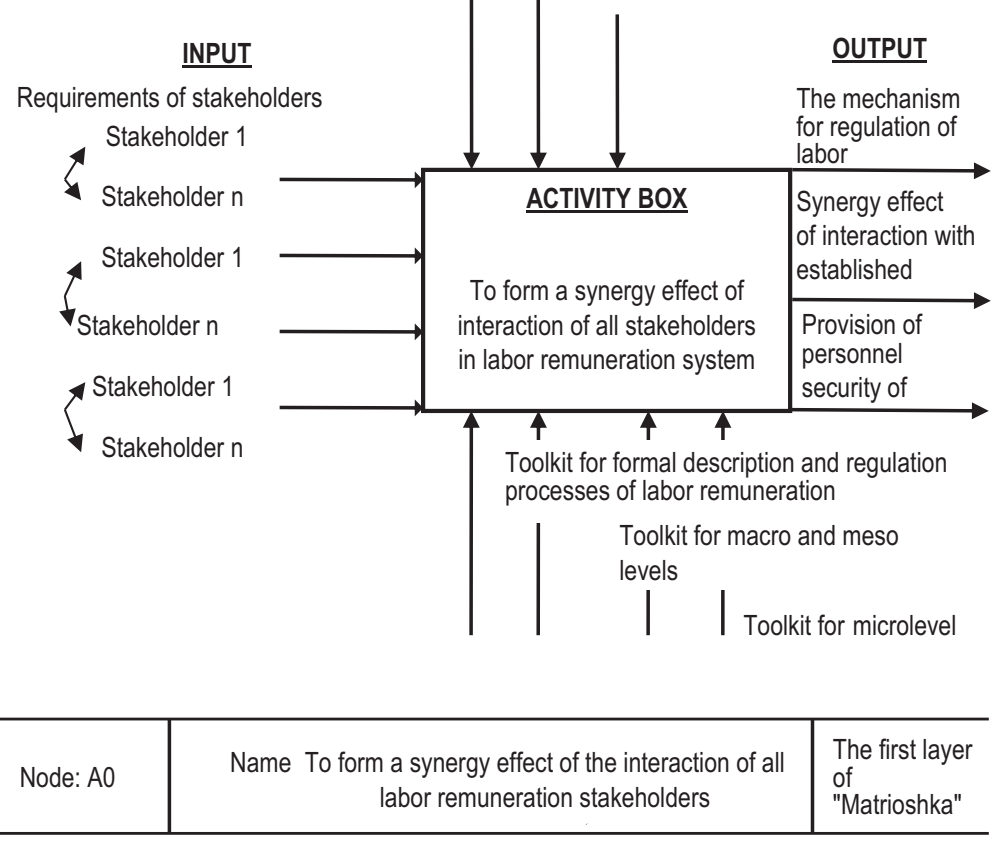

Fig. 3. Context introduction diagram of the mechanism for regulation processes of labor remuneration (the first layer of "matrioshka")

All processes are based on integrated models of three types: the first - "Class Diagram", reflects the hierarchy of the structure and behavior of classes that share the same attributes; the second one - the "dynamic model" - reflects the time horizons and the sequence of operations; the third - the "functional model" allows tracking the information component of data flows.

Diagrams of decomposition (the second layer of "matryoshka") are obtained as a result of the division of the context diagram into separate processes - these so-called functional decomposition. The third layer of 
"matryoshka" - the node tree diagrams reflect the hierarchical dependence of the processes.

The functional block Activity Box represents the provision of the function "Create a synergy effect of the interaction of all the stakeholders in the system of labour remuneration". The role and type of the interface of the four sides of the functional block are:

- the upper side "Control" - rules, strategies, procedures, standards, where it should be generated: regulatory strategic decisions, organization of monitoring of the level of labor remunerarion and personnel security of enterprises.

- the left side of "Input" - material objects or information used to obtain the result (output): the requirements of the stakeholders of the macro-, meso- and micro-levels (macro, meso, micro);

- the right side "Output" - material object or information that has been transformed into a functional block: a mechanism for adjusting the regulation processes for labor remuneration; synergy effect of interaction with the established priorities and ensuring the personnel security of enterprises.

The bottom side "Mechanism" is a tool for formal description and processes regulation of labor remuneration at macro, meso and micro levels.

The main advantage of the proposed model for processes regulation of labor remuneration is to obtain a synergy self-organization effect in order to achieve maximum efficiency from the process of regulation and minimization of personnel security risks. Each activity model has a number that consists of a prefix and number. Thus, the context-sensitive activity (the first layer of "Matrioshka") has the number A0 (Fig. 3). Activity derived from the decomposition of the context activity of this layer respectively, numbers A1, A2, A3, A4, A5 (Fig. 4).

The bottom-level decomposition work has a parent activity number and another sequential number. In our case, the decomposition activity A3 will have numbers A31, A32, A33, A34 (Fig. 5), and the decomposition activity A4 will have numbers A41, A42, A43, and A44 (Fig. 6).

In our model there are two nodes - A3 and A4 - that correspond to the decomposition of the activities "Development of the regulatory 
mechanism of labor remuneration" and "Creating synergies between personnel security and the level of labor remuneration".

Due to results of factor analysis, there are 2 factors influencing the level of labor remuneration, the degree of influence on labor remuneration processes of the first factor $-56,422 \%$, the second factor $-38,5848 \%$ (Prp. Totl tape). That is, the indicators included in these two factors account for almost $95 \%$ of regulation processes for labor remuneration.

The value of the first factor of node A31

$\Phi 1_{\mathrm{A} 31}=0,790281 \Pi 1-0,08463 \Pi 2-0,762411 \Pi 5+0,713893 \Pi 6-$ $-0,830098 \Pi 8$

where P1 - the index of real wages; P2 - the index of the number of employees, whose wages are accrued within the subsistence minimum; P5 - share of additional wages; P6 - share of incentive and compensatory payments; P8 - index of the average monthly nominal wage.

The value of the second factor of node A31:

$\Phi 2_{\mathrm{A} 31}=-0,6667481 \Pi 9+0,030554 \Pi 11$

where P9 - the ratio of the amount of arrears of wages and labor remuneration; P11 - index of indebtedness to population from wages and social payments.

The total value of the level of labor remuneration at node A31:

$\mathrm{A} 31=\frac{1}{3,414412} \Phi 1_{\mathrm{A} 31}+\frac{1}{2,230175} \Phi 2_{\mathrm{A} 31}$

Due to the results of factor analysis, the impact on the level of labor remuneration is influenced by 3 factors, the degree of influence on labor remuneration processes of the first factor $-44,3871 \%$, the second factor $-29,0302 \%$, the third factor $-13,2439 \%$ (Prp.Totl). That is, the indicators included in these three factors account for almost $87 \%$ of the impact of personnel security on the regulation processes for labor remuneration. 
The value of the first node factor A41:

$\Phi 1_{\mathrm{A} 41}=-0,709796 \mathrm{~B} 1-0,848885 \mathrm{~B} 2$

where B1 - index of movement of workers; B2 - index of the level of acceptance and drop out.

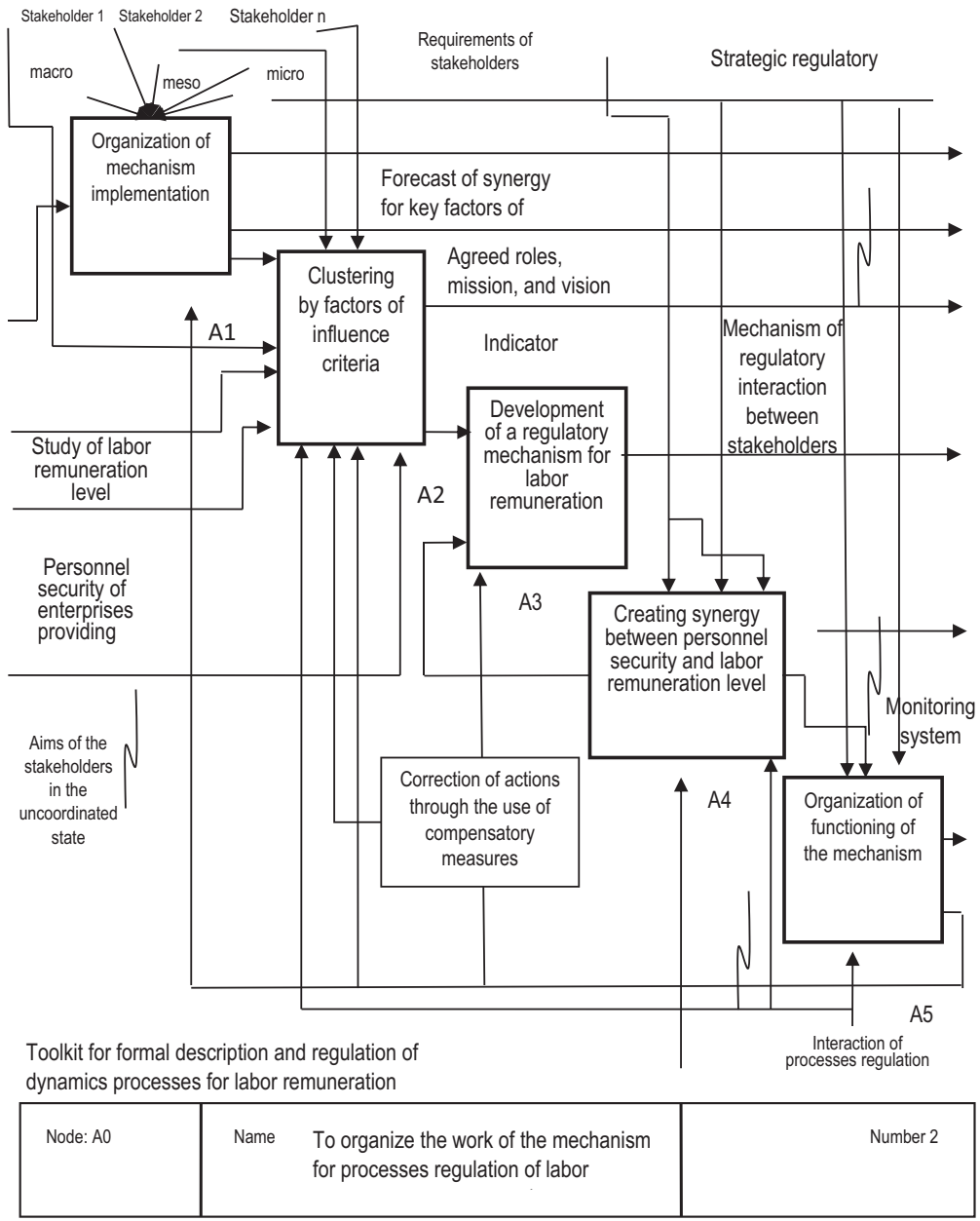

Fig. 4. The sequence of processes for organizing work of the mechanism for regulation of labor remuneration in the context of personnel security 
The value of the second node factor A41:

$\Phi 2_{\mathrm{A} 41}=-0,745867 \mathrm{~B} 5+0,858495 \mathrm{~B} 6+0,729079 \mathrm{~B} 8$

where B5 - the index of number of employees who were in forced parttime employment; B6 - index of use of working time; B8 - the index of loss of working time for reasons of stay in a university.

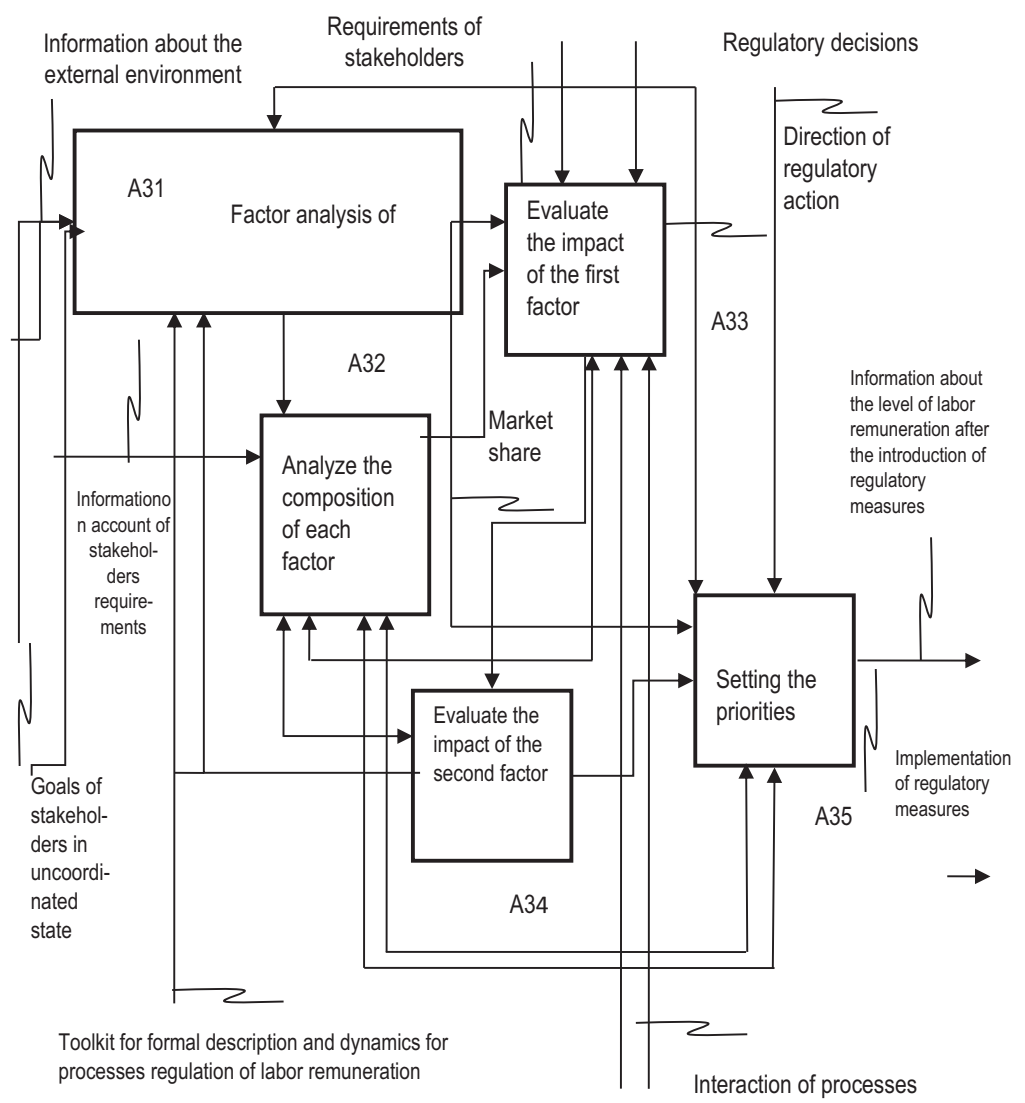

\begin{tabular}{|l|l|l|}
\hline Node: A3 & Name $\begin{array}{l}\text { To organize the work of mechanism regulating the level of } \\
\text { labor remuneration }\end{array}$ & Number 3 \\
\hline
\end{tabular}

Fig. 5. Sequence of work on the introduction of a mechanism regulating the level of labor remuneration (block A3 of reference model) 
Value of the third node factor A41:

$\Phi 3_{\mathrm{A} 41}=-0,757966 \mathrm{~B} 11$ (6)

where B11 - index of the number of collective labor disputes.

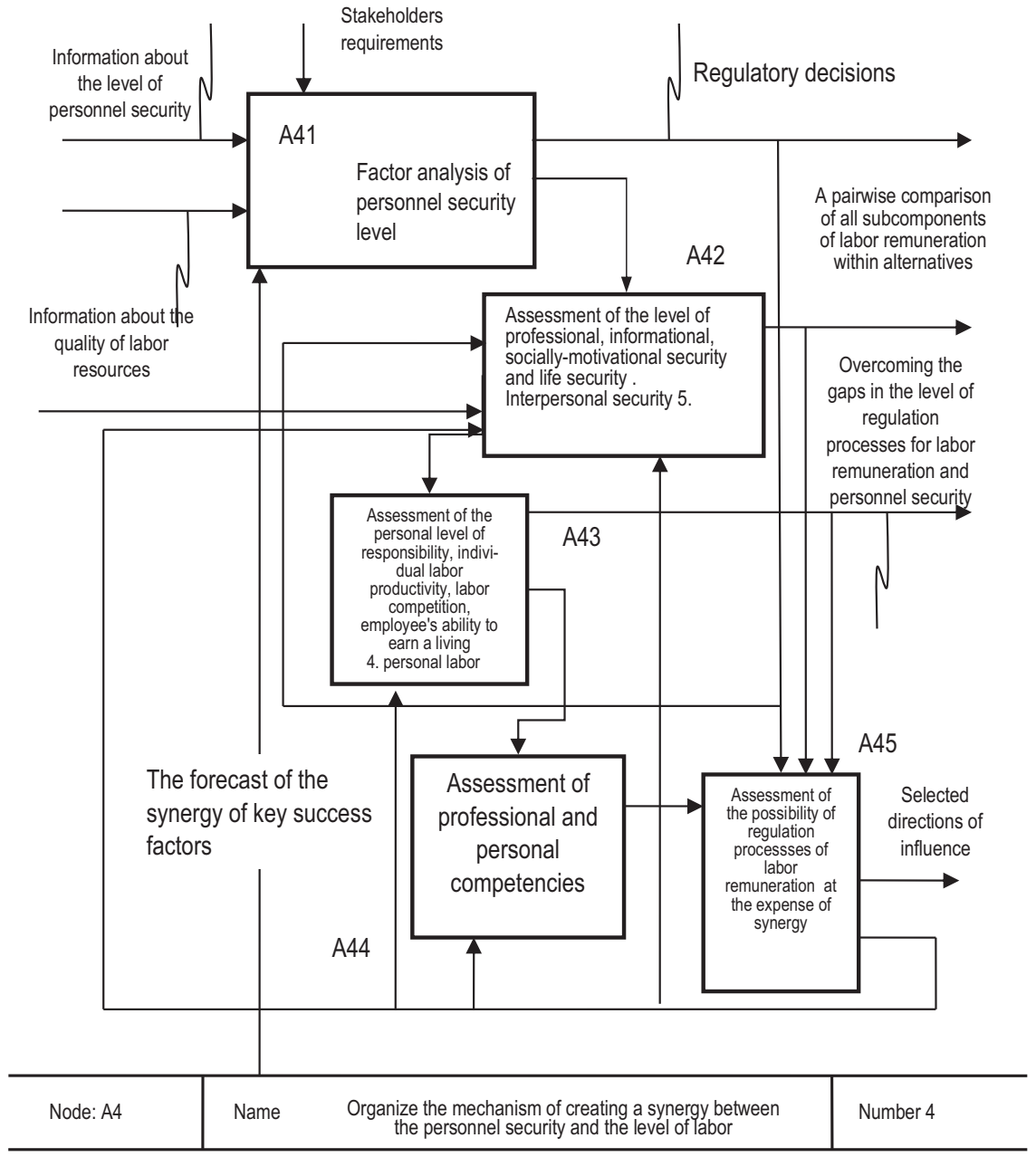

Fig. 6. Sequence on implementation work of mechanism for creating a synergy between personnel security and the level of labor remuneration (reference block A4) 
Total value of the level of labor remuneration at node A41:

$\mathrm{A} 41=\frac{1}{3,782586} \Phi 1_{\mathrm{A} 41}+\frac{1}{2,093533} \Phi 2_{\mathrm{A} 41}+\frac{1}{1,456826} \Phi 3_{\mathrm{A} 41}$

The suggested hypothesis is in the form of a matrix, where the $\mathrm{X}$-axis will reflect the value of the indicator "labor remuneration level", and Y-axis "personnel security" (Fig. 7).

According to the results of cluster analysis, the first cluster included 2 regions: Donetsk and Sumy. According to the calculations, these regions belong to the $6^{\text {th }}$ quadrant of the matrix: "RLRa; PSh - The average level of labor remuneration regulation processes at high probability of violation of personnel security.

\begin{tabular}{|c|c|c|}
\hline $\begin{array}{l}\text { RLRh; PSI } \\
\text { High level of regulation } \\
\text { processes for labor } \\
\text { remuneration at low personnel } \\
\text { threats }\end{array}$ & $\begin{array}{l}\text { RLRh; PSa } \\
\text { High level of regulation } \\
\text { processes for labor } \\
\text { remuneration at average level } \\
\text { of personnel threats } \\
7 \text { cluster } \\
\text { Luhansk region }\end{array}$ & $\begin{array}{l}\text { RLRh; PSh } \\
\text { High level of } \\
\text { regulationprocesses for labor } \\
\text { remuneration at high } \\
\text { probability of violation of } \\
\text { personnel security } \\
9 \text { cluster } \\
\text { Volyn, Zhytomyr, Rivne and } \\
\text { Chernivtsi region. }\end{array}$ \\
\hline $\begin{array}{l}\text { RLRa; PSI } \\
\text { The average level of } \\
\text { regulation processes for labor } \\
\text { remuneration at low personnel } \\
\text { risks }\end{array}$ & $\begin{array}{l}\text { RLRa; PSa } \\
\text { The average level of } \\
\text { regulation processes for labor } \\
\text { remuneration at average level } \\
\text { of personnel threats }\end{array}$ & $\begin{array}{l}\text { RLRa; PSh } \\
\text { Average level of regulation } \\
\text { processes for labor } \\
\text { remuneration at high } \\
\text { probability of violation of } \\
\text { personnel security }\end{array}$ \\
\hline $\begin{array}{l}\text { RLRI; PSI } \\
\text { Low level of regulation } \\
\text { processes for labor } \\
\text { remuneration at low personnel } \\
\text { risks }\end{array}$ & $\begin{array}{l}\text { RLRl; PSa } \\
\text { Low level of regulation } \\
\text { processes for labor } \\
\text { remuneration at average level } \\
\text { of personnel threats }\end{array}$ & $\begin{array}{l}\text { RLRI; PSh } \\
\text { Low level of regulation } \\
\text { processes for labor } \\
\text { remuneration at high } \\
\text { probability of violation of } \\
\text { personnel security }\end{array}$ \\
\hline
\end{tabular}

Fig. 7. Matrix of synergetic effect estimation of personnel safety on the level of remuneration 
The $2^{\text {nd }}$ cluster included 3 regions: Kyiv, Mykolaiv and Kharkiv. As a result of the calculations, these regions belong to the 1-st quadrant of the matrix: "RLRh; PSl - High level of regulation processes for labor remuneration at low personnel threats".

The 3rd cluster included 4 regions: Dnipropetrovsk, Zaporozhye, Kirovograd and Lviv. By results of calculations these regions belong to the $5^{\text {th }}$ quadrant of the matrix: "RLRa; PSa - The average level of regulation processes for labor remuneration at average level of personnel threats".

The $4^{\text {th }}$ cluster included 2 regions: Odessa and Cherkasy. As a result of the calculations, these regions belong to the $4^{\text {th }}$ quadrant of the matrix: "RLRa; PSl - The average level of regulation processes for labor remuneration at low personnel threats".

The $5^{\text {th }}$ cluster included 2 regions: Poltava and Chernihiv. By results of calculations, these regions belong to the $9^{\text {th }}$ quadrant of the matrix: "RLRl; PSh - Low level of regulation processes for labor remuneration at a high probability of violation of personnel security".

The $6^{\text {th }}$ cluster included 1 region: Kherson. According to the results of calculations, this region belongs to the $8^{\text {th }}$ quadrant of the matrix: "RLRl; PSa - Low level of regulation processes for labor remuneration at an average level of personnel threats".

The $7^{\text {th }}$ cluster included 1 region: Luhansk. According to the calculation results, this region belongs to the $2^{\text {nd }}$ quadrant of the matrix: "RLRh; PSa - High level of regulation processes for labor remuneration at average level of personnel threats".

The $8^{\text {th }}$ cluster included 5 regions: Vinnytsia, Zacarpats'ka, IvanoFrankivsk, Ternopil and Khmelnytsky. By results of calculations, these regions belong to the $7^{\text {th }}$ quadrant of the matrix: "RLRl; PSl - Low level of regulation processes for labor remuneration at low personnel threats" (Fig 7).

The $9^{\text {th }}$ cluster included 4 regions: Volyn, Zhytomyr, Rivne and Chernivtsi. According to the calculations, these regions belong to the 3rd quadrant of the matrix: "RLRh; PSh - High level of regulation processes for labor remuneration at high probability of violation of personnel security" (Fig. 7). 


\section{The results of quadrants positioning matrixes for appropriate directions} of regulation processes for labor remuneration in the context of personnel security are shown in Fig. 8.

\begin{tabular}{|c|c|c|}
\hline $\begin{array}{l}\text { RLRh; PSI } \\
\text { High level of regulation processes } \\
\text { for labor remuneration at low } \\
\text { personnel threats } \\
2 \text { cluster } \\
\text { Kiev, Mykolaiv an d Kharkiv } \\
\text { region. } \\
1 \text { quadrant }\end{array}$ & $\begin{array}{l}\text { RLRh; PSa } \\
\text { High level of regulation } \\
\text { processes for labor remuneration } \\
\text { at average level of personnel } \\
\text { threats } \\
7 \text { cluster } \\
\text { Luhansk region } \\
2 \text { quadrant }\end{array}$ & $\begin{array}{l}\text { RLRh; PSh } \\
\text { High level of regulationprocesses } \\
\text { for labor remuneration at high } \\
\text { probability of violation of } \\
\text { personnel security } \\
9 \text { cluster } \\
\text { Volyn, Zhytomyr, Rivne and } \\
\text { Chernivtsi region. } \\
3 \text { quadrant }\end{array}$ \\
\hline $\begin{array}{l}\text { RLRa; PSI } \\
\text { The average level of regulation } \\
\text { processes for labor remuneration } \\
\text { at low personnel risks } \\
4 \text { cluster } \\
\text { Odesa and Cherkasy region }\end{array}$ & $\begin{array}{l}\text { RLRa ; PSa } \\
\text { The average level of regulation } \\
\text { processes for labor remuneration } \\
\text { at average level of personnel } \\
\text { threats } \\
3 \text { cluster } \\
\text { Dnipropetrovsk, Zaporozhye, } \\
\text { Kirovograd and Lviv region. } \\
5 \text { quadrant }\end{array}$ & $\begin{array}{l}\text { RLRa; PSh } \\
\text { Average level of regulation } \\
\text { processes for labor remunerationat } \\
\text { high probability of violation of } \\
\text { personnel security } \\
1 \text { cluster } \\
\text { Donetsk and Sumy region. } \\
6 \text { quadrant }\end{array}$ \\
\hline $\begin{array}{l}\text { RLRI; PSI } \\
\text { Low level of regulation processes } \\
\text { for labor remuneration at low } \\
\text { personnel risks } \\
8 \text { cluster } \\
\text { Vinnitsa, Zacarpats'ka, Ivano - } \\
\text { Frankivsk, Ternopil and } \\
\text { Khmelnytskyi regions. } \\
7 \text { quadrant }\end{array}$ & $\begin{array}{l}\text { RLRI; PSa } \\
\text { Low level of regulation processes } \\
\text { for labor remuneration at average } \\
\text { level of personnel threats } \\
6 \text { cluster } \\
\text { Kherson region }\end{array}$ & $\begin{array}{l}\text { RLRI; PSh } \\
\text { Low level of regulation processes } \\
\text { for labor remuneration at high } \\
\text { probability of violation of } \\
\text { personnel security } \\
5 \text { cluster } \\
\text { Poltava and Chernihiv region }\end{array}$ \\
\hline
\end{tabular}

- the regions that fall into the matrix quadrants that need to be developed and / or modernized in regulation processes systemof labor remuneration in the context of personnel security

Fig. 8. Matrix of appropriate directions of regulation processes for labor remuneration in the context of personnel security

For further monitoring of changes in regulation processes for labor remuneration in the context of personnel security we will use the discriminat analysis toolkit in STATISTICA 10 program. The proposed system 


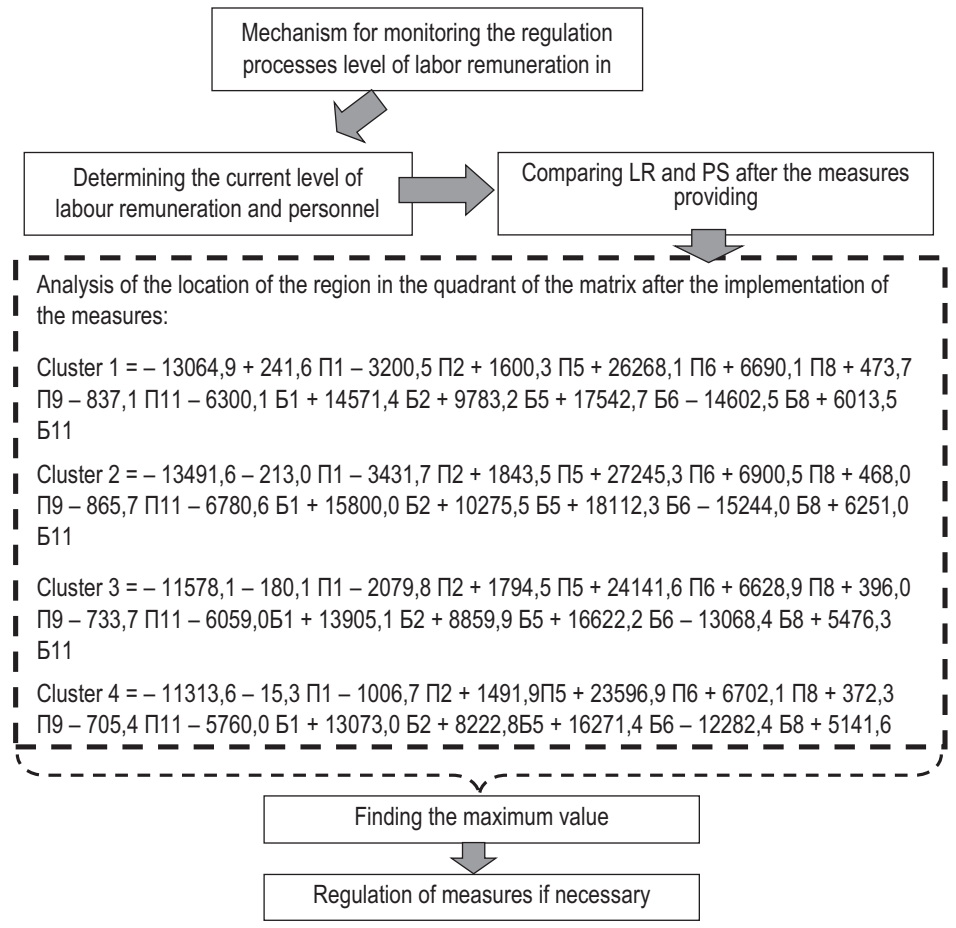

Fig. 9. Mechanism for monitoring the level of regulation processes for labor remuneration in the context of personnel security

for monitoring the level of labor remuneration in the context of personnel security using a discriminant analysis toolkit is shown in Fig. 9.

According to Fig. 9 monitoring for the level of regulation processes for labor remuneration in the context of personnel security: indicators obtained after the introduction of appropriate measures are subjected to each discriminant equation for each of the analyzed region. The maximum value of one of the nine values indicates the position obtained (quadrant of the matrix). 


\section{CONCLUSIONS}

1. There is formed the mechanism of labor remuneration in national economy, which determines macro- and meso-factors, production factors for the formation of labor remuneration system, factors of labor mobility and the formation of personnel security.

2. There are distinguished structural and functional components of the reference model for regulation processes of labor remuneration including: construction of reference model for strategic partnership in labor remuneration; determining the strength of the relationship between the tops of the reference model, the strategic partnership in labor remuneration; scenario analysis "using impulse modeling"; interpretation of the results and choice of the best option for the management of regulation processes for labor remuneration.

3. There is formed the model of regulation processes for labor remuneration with the definition of the synergy self-organization effect with the processes based on integrated models of three types: 1 - "class diagram", reflecting the hierarchy of the structure and behavior of classes that share the specific attributes; 2 - "dynamic model" reflects the time, horizons and sequence of operations; 3 - "functional model", enables track the information component of data streams.

4. There is distinguished the sequence of processes organization for the mechanism of labor remuneration regulation in the context of personnel security providing, which consists of five processes: 1 - organization of implementation mechanism 42 - clusterization by factors of influence; 3 - development of the regulatory mechanism for labor remuneration; 4 creation of synergy between personnel security and the level of labor remuneration; 5 - organization of the functioning of the mechanism.

5. There is conducted a cluster analysis on the basis of the matrix estimating synergy effect of personnel security on the level of labor remuneration of regions into one of the quadrants of the proposed matrix which made it possible to distribute Ukrainian regional enterprises to nine quadrants: from the high level of regulation processes for labor remuneration at low personnel threats to low level of regulation processes for labor remuneration at high probability of violation of personnel security. 


\section{BIBLIOGRAPHY:}

Darnton, G. (1997). Business Process Analysis. London: Tompson Business Press.

Амосов, О.Ю. (2016). Управління кадровими ризиками як елемент забезпечення економічної безпеки підприємства. Інфраструктура ринку. 2, стр. 372-376.

Гавкалова, Н.Л. (2016). Методичний підхід щодо визначення рівня формування та забезпечення кадрової безпеки підприємства. Міжнародний науковий журнал «Проблеми економіки». 4, стр. 107-113.

Геєць В.М. (ред.) (2008). Моделі і методи соціально-економічного прогнозування: підручник. Х. : ВД «ІНЖЕК».

Кибанов, А.Я. (2010). Кадровая безопасность в системе безопасности организации. Кадровик. Кадровый менеджмент. 10, стр. 30-35.

Костишина, Т.А. (2016). Оплата праці як складова соціальної політики держави. Науковий вісник Донецького національного університету. 3, стр. 66.-73

Кравченко, В.О. (2014). Кадрова безпека - основа економічної безпеки підприємства. Соціально-трудові відносини: теорія та практика: збірник наукових праць. 1 (7), стр. 301-306.

Майборода, P.Є. (2012). Статистичний аналіз даних за допомогою пакету STATISTICA: навч. посіб. К.: Видавнича лабораторія радіофізичного факультету КНУ. Marszałek-Kawa, J., Plecka, D., Hołub, A. (ed.). (2018). Social Security. Selected Aspects. Toruń: Wydawnictwo Adam Marszałek.

Назарова, Г.В. (2015). Удосконалення методики розрахунку інтегрального індексу кадрової безпеки підприємства. 1 (17), стр. 134-139.

Miгус, П. (ред.). (2014). GR- та PR-менеджмент у контексті економічної безпеки: монографія. Черкаси : ПП Чабаненко Ю.А.

Пономаренко, В.С. (ред.). (2009). Современные проблемы моделирования социально-экономических систем : монографія. Х. : ИД «ИНЖЭК».

Соломанидина, Т.О. (2011). Кадровая безопасность компании. М. : Издательство «Альфа-Пресс».

Костишина, Т.А. (ред.). (2014). Управління персоналом: теоретичні аспекти та стратегії розвитку: монографія. Полтава: РВВ ПУЕТ. 


\section{REFERENCES:}

Darnton, G. (1997). Business Process Analysis. London: Tompson Business Press. [in English].

Amosov, O.Yu. (2016). Upravlinnia kadrovymy ryzykamy yak element zabezpechennia ekonomichnoi bezpeky pidpryiemstva. Infrastruktura rynku. 2, str. 372-376. [in Ukrainian].

Havkalova, N.L. (2016). Metodychnyi pidkhid shchodo vyznachennia rivnia formuvannia ta zabezpechennia kadrovoi bezpeky pidpryiemstva. Mizhnarodnyi naukovyi zhurnal «Problemy ekonomiky». 4, str. 107-113. [in Ukrainian].

Heiets V.M. (red.) (2008). Modeli i metody sotsialno-ekonomichnoho prohnozuvannia: pidruchnyk. Kh. : VD «INZhEK». [in Ukrainian].

Kybanov, A.Ya. (2010). Kadrovaia bezopasnost v sisteme bezopasnosti orhanizatsii. Kadrovik. Kadroyi menedzhment. 10, str. 30-35. [in Russian].

Kostyshyna, T.A. (2016). Oplata pratsi yak skladova sotsialnoi polityky derzhavy. Naukovyi visnyk Donetskoho natsionalnoho universytetu. 3, str. 66.-73. [in Ukrainian].

Kravchenko, V.O. (2014). Kadrova bezpeka - osnova ekonomichnoi bezpeky pidpryiemstva. Cotsialno-trudovi vidnosyny: teoriia ta praktyka: zbirnyk naukovykh prats. 1(7), str. 301-306. [in Ukrainian].

Maiboroda, R.Ie. (2012). Statystychnyi analiz danykh za dopomohoiu paketu STATISTICA: navch. posib. K.: Vydavnycha laboratoriia radiofizychnoho fakultetu KNU. [in Ukrainian].

Marszałek-Kawa, J., Plecka, D., Hołub, A. (ed.). (2018). Social Security. Selected Aspects. Toruń: Wydawnictwo Adam Marszałek.

Nazarova, H.V. (2015). Udoskonalennia metodyky rozrakhunku intehralnoho indeksu kadrovoi bezpeky pidpryiemstva. 1 (17), str. 134-139. [in Ukrainian].

Mihus, P. (red.). (2014). GR- ta RR-menedzhment u konteksti ekonomichnoi bezpeky: monohrafiia. Cherkasy: PP Chabanenko Yu.A. [in Ukrainian].

Ponomarenko, V.S. (red.). (2009). Sovremennye problemy modelirovaniia sotsialnoekonomicheskikh sistem: monohrafiia. Kh. : YD «YNZhEK». [in Russian].

Solomanidina, T.O. (2011). Kadrovaia bezopasnost kompanii. M.: Yzdatelstvo «AlfaPress». [in Russian].

Kostyshyna, T.A. (red.). (2014). Upravlinnia personalom: teoretychni aspekty ta stratehii rozvytku: monohrafiia. Poltava: RVV PUET. [in Ukrainian]. 